\title{
Local soil knowledge and its use in crop allocation: Implications for landscape-scale agricultural production and conservation efforts in Talamanca, Costa Rica
}

\author{
Leigh A. Winowiecki ${ }^{1, ~ *}$, Matthew P. Whelan², Paul A. McDaniel ${ }^{3}$, Marilyn Villalobos ${ }^{2}$, \\ Eduardo Somarriba ${ }^{2}$
}

${ }^{1}$ Soils Research Area, International Center for Tropical Agriculture (CIAT), Nairobi, Kenya

${ }^{2}$ Tropical Agricultural Research and Higher Education Centre (CATIE), Turriabla, Costa Rica

${ }^{3}$ Plant, Soil and Entomological Sciences Department, University of Idaho, Moscow, Idaho, USA

Email address:

1.a.winowiecki@cgiar.org (L. A. Winowiecki)

To cite this article:

Leigh A. Winowiecki, Matthew P. Whelan, Paul A. McDaniel, Marilyn Villalobos, Eduardo Somarriba. Local Soil Knowledge and Its Use in Crop Allocation: Implications for Landscape-Scale Agricultural Production and Conservation Efforts in Talamanca, Costa Rica.

Agriculture, Forestry and Fisheries. Vol. 3, No. 2, 2014, pp. 93-101. doi: 10.11648/j.aff.20140302.17

\begin{abstract}
Smallholder farmers have developed knowledge about soil and crop management through long-term, on-farm observations. Yet, food insecurity and land degradation continue to threaten livelihoods, globally. Part of the solution lies in linking local and scientific knowledge to develop improved agricultural strategies. We argue that incorporating farmer knowledge in the design and/or technology transfer processes of land management and restoration projects will improve the likelihood of success. The objectives of this study were to understand how farmers in the remote Cabécar communities in southeastern Costa Rica use soil knowledge to allocate and manage crops and to explore how to combine local and scientific knowledge to achieve wider adoption of sustainable agricultural techniques. Cabécar farmers in the foothills of the Talamanca Mountains practice both no-input subsistence and cash-crop farming. They cultivate both annual and perennial crops on their multi-parceled farms. Twenty-three stratified random heads of households were selected and interviewed. A variety of participatory methods were used including, participant observation (1.5 years), semi-structured interviews, farm mapping exercises, farm-transect walks and a participatory community workshop. Results indicate that farmers identified three distinct soil types using primarily soil color, texture and landscape position. Most interestingly, farmers' understanding of soil properties was tied directly to site suitability for specific crops. While farmers identified limitations of certain soil types' capacity to sustain a particular crop, farmers did not embark on restoration efforts or employ nutrient management techniques to improve the productivity of the soil. Furthermore, farmers had limited knowledge on processes of soil development and nutrient cycling. Instead of amending the soils to increase productivity, farmers allocated crops according to existing perceived suitability of the soil. These insights illustrate the barriers to farmer's adoption of new agricultural strategies. These data and experiences will be used to guide future agricultural research in the region, specifically projects that promote the restoration of unproductive soils by providing alternatives to burning and incorporating organic amendments.
\end{abstract}

Keywords: Local Soil Knowledge, Agroforestry, Costa Rica

\section{Introduction}

Farmers develop soil knowledge by conducting long-term observational experiments on their farm. Utilizing these experience-based insights and incorporating the knowledge of local people, whose livelihoods depend on the land, can improve the communication between researchers and farmers and potentially improve the success of extension projects. Local knowledge develops through experience over time and is unique because it seamlessly incorporates both historical and cultural context (Winklerprins, 1999; Oudwater and Martin, 2003), and is embedded in land-management practices (Krogh and Paarup-Laursen, 1997; Sillitoe, 1998). Previous studies have highlighted several benefits of integrating local soil knowledge into projects including: addressing the immediate needs of the local people (Winklerprins, 1999); increased success of sustainable development and conservation projects 
(Winklerprins, 2001; Barrios and Trejo, 2003, Boreux et al., 2009); expanding available datasets by including historical accounts (Huntington, 2000); and the development of GIS soil databases that incorporate both local and scientific soil classifications to create land-use suitability indices (Gobin et al., 1998, 2000; Barrera-Bassols et al., 2006). However, it is also important to acknowledge that farming communities do not always have the opportunity to farm the most productive lands (Ryder, 2003) and that local soil knowledge may also include recent agricultural extension efforts (Winklerprins and Barrera-Bassols, 2004). Recently, studies of local soil knowledge have shifted from documenting local soil classification systems to incorporating farmers' knowledge in the development of holistic soil management approaches (Talawar and Rhoades, 1998; Winklerprins and Barrera-Bassols, 2004; Barrios et al., 2006). For example, national ecosystem assessments are combining qualitative local knowledge with quantitative soil data to better understand land degradation in the USA (Herrick et al., 2010). Due to the complex nature of local knowledge, some authors suggest research should focus more on problem-oriented knowledge integration processes, rather than merely how to integrate the knowledge systems (Raymond et. al., 2010). Methods that capture and incorporate farmer knowledge in order to prioritize local needs are still much needed.

Many biophysical, cultural, and socio-economic factors influence farmers' selection of crops and development of land-management practices over time (Dove, 1985; Schusky, 1989). These factors include local, regional, and international economies and markets, cultural knowledge, site suitability, climate, native soil fertility and soil characteristics, availability of labor and land, the influence of extension agents and the sharing of knowledge among farmers. All of these factors are often considered simultaneously and incorporated into local soil knowledge decision-making processes.

The Cabécar indigenous territory in southeastern Costa Rica provides an excellent study area to investigate local soil knowledge and demonstrate its application for incorporation into improved land management strategies. The indigenous territory borders two national parks and encompasses large tracts of forests, with smallholder subsistence and cash crop farmers living within this matrix. The territory lies within the northern foothills of the Talamanca Mountains and is part of the proposed Meso-American Biological Corridor, which aims to conserve and connect coastal and montane ecosystems. Due to its location and high conservation value to preserve structural connectivity within the corridor, the indigenous territory has been the center of several development projects promoting agricultural diversity (Dahlquist et al., 2007) and biodiversity conservation in cacao agroforestry systems (Andrade and Detlefsen, 2003; Somarriba et al., 2003). Yet, despite more than 20 years of extension efforts in the area, little is known about the local ecological knowledge of the Cabécar indigenous people (Whelan, 2005). The objectives of this research were threefold: 1) to assess if and how farmers distinguished between different soil types on the landscape; 2) to understand how farmers expressed soil knowledge through crop allocation; and 3) to suggest how to incorporate these data into development projects and land-management strategies.

\section{Materials and Methods}

\subsection{Study Area}

The Talamanca region in southeastern Costa Rica borders Panama and is home to the Cabécar people (Figure 1). The Cabécar indigenous territory was established in 1977 by the Costa Rican government. It is 23,000 ha in size and supports a population of 3,500 (Andrade and Detlefsen, 2003). Cultural remains indicate that the Cabécar and other indigenous peoples have existed in the Talamanca region for over 3000 years (Borge and Castillo, 1997). Yet, they battled with Spanish conquistadors, Chiriquí Land Company (later know as United Fruit Company (UFC)), oil exploration initiatives and hydroelectric companies to maintain their presence in the region (Somarriba, 1993; Villalobos and Borge, 1998). For example, communities were relocated to accommodate the expansion of banana in Talamanca for UFC, but returned between 1940 and 1970 to reclaim their land and livelihoods in the Talamanca valley and foothills. Currently, the indigenous Cabécar smallholder farmers inhabit the Talamanca Mountain foothills and small portions of the alluvial valley. They practice both subsistence agriculture and cash-crop production, including organic banana (Musa AAA) and cacao (Theobroma cacao) agroforestry systems, shifting cultivation (rotation of basic grain crops and fallow) systems, as well as chemical-intensive plantain (Musa AAB) production (Somarriba and Harvey, 2003). Talamanca is the poorest canton in Costa Rica (Municipalidad of Talamanca, 2003) and farmers continue to face marginalization due to limited infrastructure and limited access to markets and health care (Gomez, 2001).

Geomorphologically, the Atlantic Slope of the Talamanca Mountains contains three distinct regions: the Talamanca Valley, which covers about 12,000 ha $(18 \%$ of the territories) and contains $80 \%$ of the population within the Bribri and Cabécar indigenous territories (Borge and Castillo, 1997); the foothills, ranging in elevation from $100-600 \mathrm{~m}$; and mountainous terrain above $600 \mathrm{~m}$. Average annual temperature of the study region is $25{ }^{\circ} \mathrm{C}$ and annual precipitation is between $2200-3100 \mathrm{~mm}$ (Kapp, 1989).

No official soil survey has been conducted in Talamanca, but in general, the dominant soil type in the alluvial floodplains is classified as an Entisol and the foothill slopes are dominated by Inceptisol and Ultisol soil orders (Borge and Castillo, 1997, Polidoro et al., 2008). The Talamanca Mountains and associated foothills are rugged, remote, and prone to natural disasters such as landslides and flooding. 
Yet, farmers cultivate the land throughout the entire region. Due to its difficulty to access, the Talamanca region lacks well-documented biophysical and agricultural data and thus provides an excellent example to utilize local knowledge to better understand indigenous smallholder farming techniques.

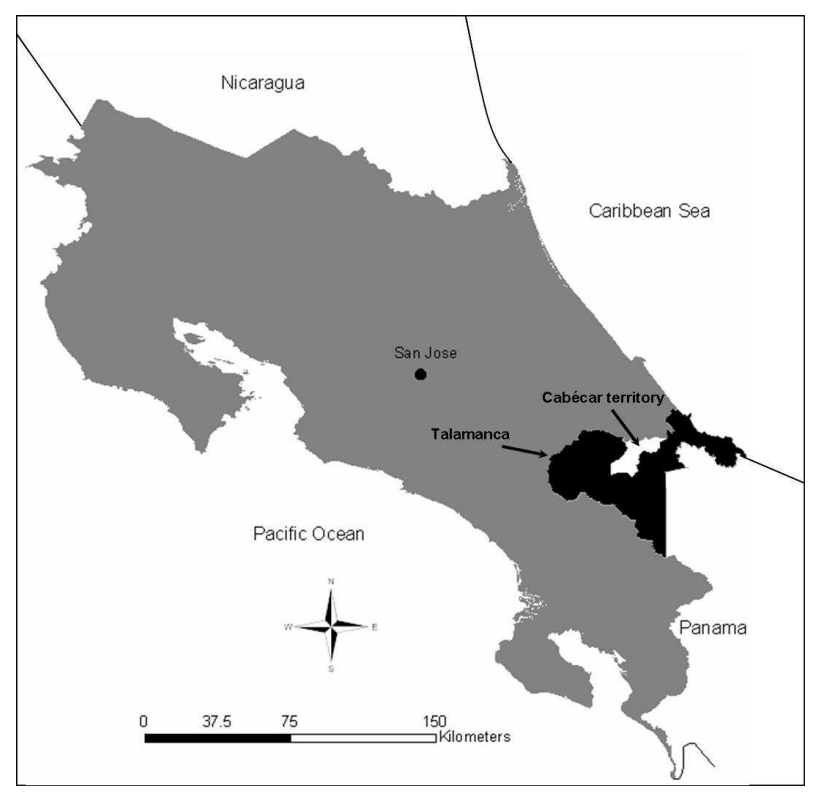

Figure 1. Location map of the Cabécar Indigenous Territory in southeastern Costa Rica.

\subsection{Selection of Communities and Households}

Communities were selected based on the following criteria: 1) ample, available land resources to practice subsistence, rotation, and cash-crop agriculture; 2) close proximity $(\sim 7 \mathrm{~km})$ to each other with similar landforms; 3 ) homogenous ethnicity; and 4) willingness to accept us into their community. Three Cabécar communities (Sibuju, San Miguel, and San Vicente) were selected for the study, as these were representative of communities residing in the foothill region.

Twenty-three households were selected using a stratified random sampling design. Combined, the three Cabécar communities have approximately 75 households, which were stratified into three categories based on age of head of household: 20-40-, 40-60- and over 60-years old. Random samples were drawn from each category until roughly $30 \%$ of community was reached.

\subsection{Participant Observation and Open-Ended, Semi-Structured Interviews}

Communities, farms and farmers were visited repeatedly over the course of 1.5 years (June 2005 to December 2006) to observe farming practices, soil properties and management strategies and to discuss farming techniques with farmers. Five preliminary interviews were conducted with farmers during this time to help design future interview questions.

Subsequently, semi-structured, open-ended interviews with the head of the household were conducted between
January and March 2006 at the farmer's farm by the two lead authors. The main objectives of the interviews were to determine if farmers distinguished between different soil types in the region, how farmers described soil, if crops were allocated according to soil type and what management strategies farmers utilized for each crop and soil type. Basic information (size of household, land area farmed, etc.) about each household was also gathered. Average length of the interview was $\sim 3$ hours. Several family members often accompanied the head of household during the interview.

\subsection{Participatory Mapping Exercise: Current and Historical Land Use}

The household members drew maps of their farm, including the location of each parcel within the farm, indicating the size of each land use and the crops planted. Landscape attributes and land-use history of each parcel was also recorded. For example, if a parcel currently was in fallow, we asked how long it has been in fallow and what the cropping cycles have been, including how the plot was managed, and if the land was burned for each rotation. Areas of different soils, as recognized by the farmers, were indicated on the farm map.

\subsection{Farm Transect Walks}

Following the mapping exercise, farm transect walks were conducted to provide another opportunity to discuss soil types and crop suitability in the field as well as to validate the information collected during the interviews. After each interview, farmers selected transects across their farm to show the different soil types they described earlier. We excavated the soil to examine and describe it. Observations and discussion about crop allocation, suitability and productivity occurred at each soil observation point. Locations were revisited at a later time to dig soil pedons and collect soil samples (Section 2.8).

\subsection{Participatory Community Workshop}

In addition to participant observation and farm transect walks, a community workshop was held after all these data were compiled in order to triangulate the results. The workshop was held at a local community center on September 29, 2007. Data were presented orally as well as in written form. All community members were invited, including farmers who were not interviewed. Additional questions were asked at the workshop. The objectives of this workshop were to: 1) assess if we accurately interpreted the farmers' knowledge from the interviews; 2) determine if farmers agreed on the different soil types in the region and the crop allocation patterns on these soil types; and 3) provide an additional forum (semi-formal community meeting) for farmers to share their soil knowledge with community members and researchers.

\subsection{Qualitative Data Analysis}

Extensive notes were taken during all interviews and the 
workshop. All notes were transcribed and typed. Data were compiled, analyzed and interpreted according to basic qualitative procedures (Creswell, 2003). Data (responses) were organized into categories and themes were identified. Responses under each theme were quantified using descriptive statistics.

\subsection{Soil Sampling}

Soil pedons were sampled on the same farms where the interviews were conducted ( $\mathrm{n}=9$ farms), and according to the soil types identified by the farmers. Since farmers associated soil types with specific landscape positions, three pedons were excavated on the three different landscape positions (alluvial flood plain, sloping lands and low lying areas (e.g. depressions)). Samples were taken by genetic horizon and transported to the University of Idaho Pedology Laboratory. Soil samples were air dried, gently crushed, and sieved to < $2 \mathrm{~mm}$. Sand, silt, and clay contents were determined using wet sieving, sonification, and centrifugation (Gee and Bauder, 1986). pH was measured on a 1:1 (soil:deionized water) slurry with standard $\mathrm{pH}$ electrode (Thomas, 1982). Exchangeable cations ( $\mathrm{Ca}, \mathrm{Mg}$, and $\mathrm{K}$ ) were extracted using $\mathrm{NH}_{4} \mathrm{OAc}$ and leachate was analyzed using inductively coupled plasma (ICP) spectroscopy (Sumner and Miller, 1996). Soils were classified using both Soil Taxonomy (Soil Survey Staff, 2006) and World Reference Base for Soil Resources (IUSS Working Group WRB, 2006).

\section{Results}

\subsection{Demographic Information}

Twenty-three households were interviewed in three Cabécar indigenous communities (Sibuju, San Vicente and San Miguel), representing 30\% of the total number of households. Ninety-one percent of the interviews were conducted with men as head of the household and two interviews were conducted with widowed women. Head of household age ranged from 26 to 75 years old, with six households in the 20-40-year-old category, 11 in the 40-60-year-old category and six in the over 60-year-old category. Average number of household members for all three communities was five. Seventy percent of the Cabécar farmers interviewed were not born in the community where they currently live. Length of time the head of household has lived in the current community ranged from four to 45 years, with a mean of 27 years.

Principal crops identified by farmers include rice (Oryza sativa), maize (Zea mays), beans (Phaseolus vulgaris), cacao (Theobroma cacao), banana (Musa AAA) and plantain (Musa AAB).

\subsection{How Famers Describe Soil}

Talamanca foothill farmers used primarily color and texture to distinguish between soil types. Farmers were asked what types of soil exist on their farm. Ninety-six percent of farmers identified two distinct soil types and called them Red soil ("tierra colorada") and Black soil ("tierra negra") (Table 1). The remaining four percent did not identify a Red or Black soil. When asked what soils exist in the larger region, seventy percent of farmers described a Sandy soil ("tierra arenosa") located in the alluvial floodplain. It was often challenging for a farmer to describe the soil without relating it to a crop or landscape position. Yet, $74 \%$ of the farmers described Red soil as being hard. Terms such as dry, sticky, clayey, sterile and occurring on sloping lands or ridgetops were also used (Table 1). Fifty-two percent of the farmers described Black soil as smooth. Other descriptors included loose, moist, sandy and found in low-lying areas of the landscape (Table 1). All participants who identified Sandy soil described it as sandy, best for plantain production and occurring in the alluvial floodplain. Since many of the households moved from and farmed on the opposite side of the Talamanca Mountains, farmers were asked to describe the soil there. Pacific-slope soils were described as dry, sterile, and less productive than soils of the Atlantic Slope.

Only half of the households recognized soil depth as characteristic of the soil. Talamanca farmers do not plow or use mechanization on the farm, and basic grain crops do not require deep planting. Therefore they do not regularly examine the soil below 30-cm depth. Exposed riverbanks, landslides, tree falls and scarce road cuts provided opportunities for farmers to observe subsurface soil.

Table 1. Descriptive words (in Spanish with English translation) used by farmers to describe the three soil types ( $n=23$ interviews).

\begin{tabular}{llll}
\hline $\begin{array}{l}\text { Soil Type (\% of } \\
\text { Households } \\
\text { who Identified } \\
\text { this) }\end{array}$ & $\begin{array}{l}\text { Farmer } \\
\text { Description } \\
\text { (Spanish) }\end{array}$ & $\begin{array}{l}\text { English } \\
\text { Translation }\end{array}$ & $\begin{array}{l}\text { \% of } \\
\text { Respondents } \\
\text { using this } \\
\text { Description }\end{array}$ \\
\hline Red Soil (96) & Duro & Hard & 74 \\
& Pegajoso & Sticky & 48 \\
& Arcilloso & Clayey & 35 \\
& Seco & Dry & 22 \\
& Estéril & Sterile & 9 \\
& Altas, montaña & Steep, & 61 \\
& sloping land & 61 \\
Black Soil (96) & Suave & Smooth & 52 \\
& Suelto & Loose & 39 \\
& Arenoso & Sandy & 35 \\
& Húmedo & Moist & 17 \\
& Bajuras, bajos & Low-lying & 57 \\
& areas & 57 \\
& Arenoso & Sandy & 70 \\
& Suelto & loose & 17 \\
& Arena mesclado & Sand mixed & 13 \\
& con tierra & with soil & \\
& La isla & floodplain & 70 \\
\hline
\end{tabular}

In general, Talamanca farmers use basic visual and textural observations to describe the soils in their region. Similarly, smallholder farmers in southwestern Nigeria used texture and color, as well as visual perception of drainage and soil density to classify soil (Osunade, 1988). Soil classification of rural farmers in Mexico and Burikna Faso was based on soil color, texture, consistency and moisture retention (Williams and Ortiz-Solorio, 1981; Dialla, 1993). 
These studies report that farmers designated different soil types using soil characteristics that were visually observable or physically discernable, referring mostly to surface horizons.

\subsection{Crop Suitability and Implications for Agricultural Productivity}

Farmers commonly discussed each soil type within the context of crop suitability. Through experimentation, farmers have learned that pasture, upland rice (Oryza sativa), peach palm (pejibaye) (Bactris gasipaes), coffee (Coffea robusta), pineapple (Ananas comosus) and oranges (Citrus aurantium) were suitable crops for Red soil (Table 2). Red soil was stated as being suitable for houses and other structures. In contrast, the Black and Sandy soil types were viewed as highly productive and fertile soils that supported the cultivation of most local crops including beans (Phaseolus vulgaris), maize (Zea mays), banana (Musa AAA), plantain (Musa AAB), cacao (Theobroma cacao), and cassava (Manihot esculenta) (Table 2).
Farmers also associated crop success with each soil type. While a specific crop may grow on the Red soil, its yield was reported to be too low to continue cultivation in the future. Yet, Red soil is the dominant soil type in the foothill region. When asked how farmers rehabilitate the Red soil to make it more suitable for cultivation, farmers stated that the soil needed to rest (e.g., as fallow) and/or they converted the land into pasture. Soil conservation measures were not mentioned or observed.

Talamanca farmers are not alone in establishing soil types that are strongly correlated to crop suitability. Farmers in Burkina Faso associated each soil type with site suitability for specific crops (Dialla, 1993, Ericksen and Ardon, 2003). Habarurema and Steiner (1997) noted that farmers in Rwanda classified soil based on agricultural suitability, and little correlation was found between farmers' soil classification scheme and Soil Taxonomy (Habarurema and Steiner, 1997). This type of knowledge is extremely useful for planning and executing agricultural extension programs.

Table 2. Suitable crops and associated management/conservation techniques identified by the interviewed households, listed for each soil type (AFS= agroforestry system).

\begin{tabular}{llll}
\hline Soil Type & Farmer-identified Suitable Crops & Management Techniques & Limitations Identified \\
\hline Red Soil & Citrus & No input/manual weeding/pruning & --- \\
& Coffee & No input/manual weeding/pruning & Landslides/low yield \\
& Pasture & No input/low density & Hardening of soil \\
& Peach Palm & No input & No input/low density \\
& Pineapple & No input/manual weeding/burning & Landslides/high weed density \\
& Upland Rice & No input/manual weeding/burning & Landslides/low yield \\
Black Soil & Beans & No input/manual weeding/burning & Landslides/high weed density \\
& Maize & Organic AFS & Low yields/disease \\
& Cacao & Organic AFS & Pests and disease \\
& Banana & No input/manual weeding/burning & Landslides/high weed density \\
& Upland Rice & No input/manual weeding & Flooding and disease \\
& Cassava & Monoculture/inorganic fertilizer/pesticides/nematicides & Floding and disease \\
& Plantain & Organic AFS & Flooding \\
& Banana & No input/manual weeding/burning & \\
\hline
\end{tabular}

\subsection{Landscape Position}

The Talamanca foothill region is an undulating and diverse landscape. In fact, farmers, often discouraged, described the landscape as broken "quebrada", uneven, or hilly. Sixty-one percent of farmers referred to the Red soil as the soil that is on the ridgetops. Fifty-seven percent of farmers described the Black soil as existing in the low-lying lands or upland depressions. Seventy percent of farmers specifically described the Sandy soil as existing in the alluvial floodplain in the valley. This information is invaluable when conducting a reconnaissance soil survey in the area.

A few farmers explained their understanding of this landscape-soil relationship by illustrating how rain washes ("se lava") the Black soil away from the ridgetops and slopes and deposits it in these low-lying areas ("bajuras"). Similarly, farmers in Burkina Faso described four different soil types in their region that were linked to directly to different landscape positions (Gray and Morant, 2003). It is important to understand how farmers view the soil and its formation in order to better communicate soil processes and soil-management strategies that influence these processes.

\subsection{Land-use Trajectory}

Talamanca foothill farmers managed between one and five farms with an average of 2.7 farms per head of household with an average combined farm size of 47 ha. Farmers often managed a farm near their home and other farms located in a different community. This results in a patchwork of land ownership throughout the landscape and provides a variety of landforms for each individual farmer to cultivate and manage. In addition to having several farms, Talamanca farmers divided their farms into different parcels. Foothill farmers managed between 4 and 13 parcels within their farms, with each parcel potentially having a variety of land-management strategies, history or soil type. Figure 2 illustrates the land-use trajectory of a typical foothill farmer who has a topographically diverse farm and a number of 
land uses within the farm. Historically, all parcels were managed similarly for the cultivation of basic grains. For example, a forested area within the farm was selected for conversion to basic grain production (0.25-1 ha), which included slash and burning. After one cropping season, the parcel was allowed to go into a fallow period and a new parcel of forested land was selected for conversion for the next season. In summary, this 52-ha farm was slowly slashed and burned, one hectare at time, until after several years, the entire farm had been subjected to cultivation. A shift in this land-use pattern occurred when perennial crops were introduced on this farm. Site selection of perennial crops is an important decision for the farmer, as the crop will likely exist on the site for 5 to 50 years.

Farmers reported using landscape position, observation of soil characteristics and experience from past production of the basic grains to help decide where to plant the perennial crop. For example, beans were considered a more sensitive crop than upland rice and required more fertile and less-steep land. Therefore, if beans produced well on a particular parcel, the farmer assumed that perennial crops would also produce well and this location was selected for the introduction of agroforestry systems.

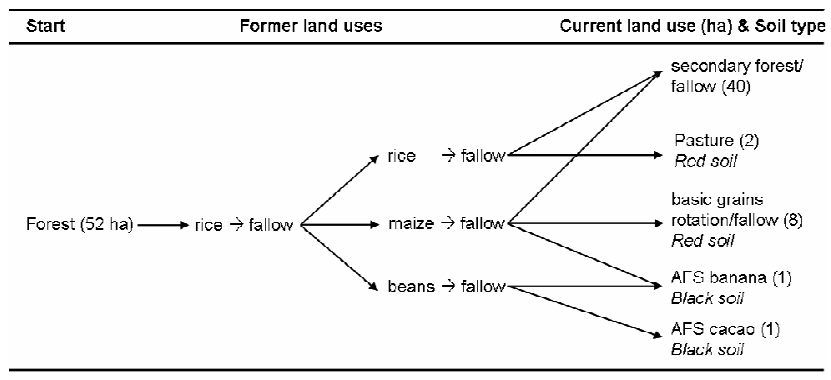

Figure 2. Land-use trajectory of a typical farm in the foothills of Talamanca. The farm was divided into five parcels, all of which were managed similarly until the inclusion of perennial crops and pasture (AFS is agroforestry system).

\subsection{Soil Chemical and Physical Characteristics}

Morphological, physical, and chemical differences existed between the three soil types identified by farmers. As the names suggest, Red and Black soil have moist soil colors that are considerably different (Figure 3). Mean clay concentrations in each soil type were significantly different from each other $(\mathrm{p}<0.05)$, with the Sandy soil having the lowest mean clay concentration $(22 \%)$, followed by the Black soil (45\%) and the Red soil (54\%) (Figure 3). Mean $\mathrm{pH}$ values ranged from 4.5 for the Red soil to 6.9 for the Sandy soil (Table 3). Apparent effective cation exchange capacity (ECEC) is a measure of the clay fraction's contribution to the cation exchange and storage capacities of the soil. A low apparent ECEC value of $12 \mathrm{cmol}_{\mathrm{c}}$ per $\mathrm{kg}$ of clay or less indicates a soil dominated by low-activity, kaolinitic clay (Soil Survey Staff, 2006). Sandy soil had the highest mean apparent ECEC, indicating high-activity clays present, while the Red soil, had relatively low ECEC (Table 3).
Table 3. Mean $\mathrm{pH}$ values and apparent effective cation exchange capacities (ECEC) per kg of clay for soil horizons in each of the three soil types identified by farmers.

\begin{tabular}{lllllll}
\hline & pH & & \multicolumn{5}{c}{ ECEC $\left(\mathbf{c m o l}_{\mathbf{c}} \mathbf{k g ~ c l a y}^{-1}\right)$} \\
\hline Soil & $\mathrm{n}$ & Mean & Range & $\mathrm{n}$ & Mean & range \\
Type & & & & & & \\
Red & 18 & 4.5 & $4.2-4.7$ & 11 & 30 & $17-58$ \\
Black & 15 & 5.0 & $4.4-6.3$ & 11 & 49 & $26-72$ \\
Sandy & 18 & 6.9 & $5.6-7.7$ & 8 & 169 & $109-295$ \\
\hline
\end{tabular}

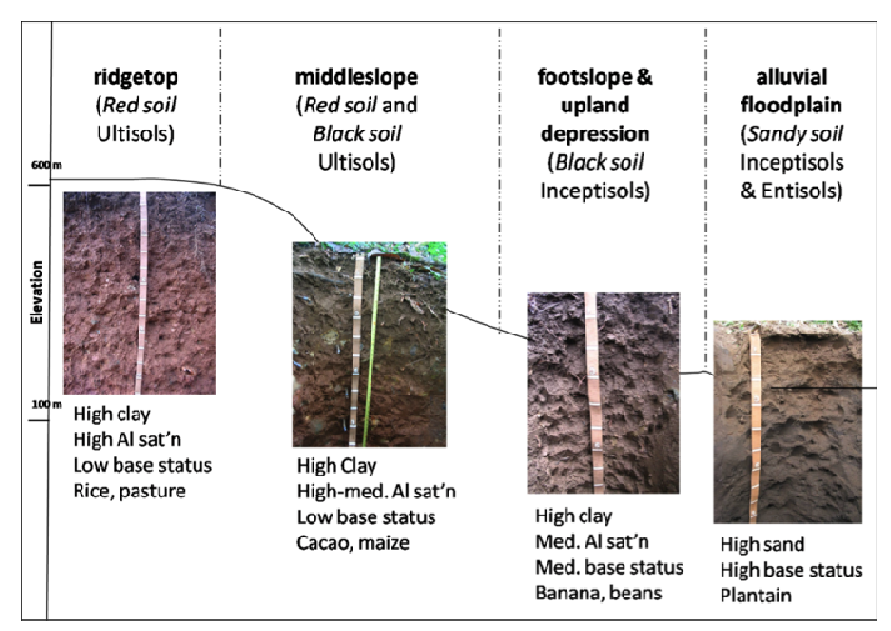

Figure 3. Landscape position, farmer classifications, US Taxonomy classification, soil characteristics and crop suitability of soil of the Talamanca foothills.

\subsection{Relating Soil Chemical Indicators and Local Soil Knowledge}

Soil chemical analyses have important implications for soil fertility and availability of nutrients. For example, due to the low storage and exchange capacities of the Red soil, management techniques that encourage efficient biocycling and minimize losses due to leaching are needed in order to continue to farm on the Red soil. Soil chemical characteristics are also reflected in crop productivity. Farmers state that neither banana, plantain, nor maize produce well in the Red soil. This could be due to the high clay content inhibiting growth of fine roots, the low base status unable to satisfy the nutrient requirements of the crop, or potentially high Al saturation inhibiting root growth and nutrient uptake. While farmers have no way to chemically measure soil fertility, their observations of crop productivity gave an accurate perception of the fertility of the soil. Farmers perceived Black soil as better for crop production than the Red soil. Though $\mathrm{pH}$ values of Black soil are still considered acidic and clay content is comparable to the Red soil, the higher ECEC of the Black soil makes it more suitable for most crops compared to the Red soil.

The three soils types identified by farmers are also classified differently using Soil Taxonomy (Figure 3). Due to their low base status and clay-rich subsoil, Red soils were classified in Soil Taxonomy as Ultisols (Udults). Black soils were classified as Inceptisols (Udepts). Sandy soils were classified as Entisols (Fluvents) due to their high base status and that they formed in alluvial sediments. 


\section{Conclusions and Discussion}

\subsection{Changing Soils}

Farmers commented on the current and historic soil characteristics of their farm, noting if the soil had changed since they first started cultivating it less than 40 years ago. Seventy percent of households reported that the soil had changed negatively over this time period. Thirty-nine percent of these farmers indicated that landslides had a large impact on the land. In addition to landslides, $56 \%$ commented that soil had changed due to the continual practice of slash-and-burn-agriculture. Farmers also commented that burning led to soil sterilization and low productivity due to overuse. In addition, all of the farmers in the over 60-year-old category referred to the soil on Pacific Slope as sterile due to over-burning. Despite this, $96 \%$ of the farmers interviewed burned regularly. During the community workshop, farmers actively debated the necessity of burning. The most common argument for burning was weed control. Yet, other farmers suggested a labor-intensive alternative of manually mulching the fallow vegetation and planting the crop within this mulch layer. It is important to note that while farmers acknowledge that the soil had changed over time, they did not see themselves as agents to make a positive change toward rehabilitating the soil. This is an important barrier to overcome for a successful implementation of soil improvement programs in the area.

\subsection{Soil Management and Restoration Efforts}

Despite the limited fertility of some foothill soils and in contrast to many other regions around the world, Talamanca farmers do very little to no active land manipulation to improve soil conditions for crop production. This may, in part, be due to the large farm sizes within the region. Talamanca foothill farmers designated overused soil (often Red soil) as tired ("cansado") and converted the land use to pasture or fallow. Pasture was seen as a final land use and farmers did not report converting pasture to any other land use. As population continues to increase, management practices that put these Red Soils back into production will be needed. Extension projects also need to address the disconnect Talamanca farmers have concerning their possible role in soil degradation and their ability to manipulate the land to create favorable soil conditions.

Farmers mentioned that trees provide several benefits including timber, shade, fruit and protection of natural springs (water sources). However, no active tree planting to promote these benefits was observed. Most farmers kept shade trees on their farm for their timber value or fruit production. In similar studies conducted in Chiapas, Mexico, organic coffee farmers remarked that shade trees provided litterfall, which contributes to soil formation, yet farmers did not recognize the role of trees in maintaining soil moisture or enhancing nutrient uptake (Grossman, 2003).

There are several potential explanations for the lack of soil management techniques employed in Talamanca. For example, no extension efforts have promoted the application of organic amendments; market values for crops are too low to encourage applying or paying for amendments; and only inorganic fertilizers are readily available on the local market, which are not suitable for organic cacao and banana production. Despite these potential obstacles, soil-management techniques are needed, especially on the Red soil. Identifying these obstacles and how farmers view the soil will aid in communicating and developing sustainable land-management techniques.

\subsection{Combining Knowledge Systems}

The fusion of these learning systems has the potential to play an important role in improving land management strategies and enhancing conservation efforts in the Talamanca Indigenous Reserves. For example, addressing the disconnect in farmers' knowledge regarding their role and ability to improve (or degrade) the soil will help improve dissemination of new technologies (e.g., techniques that enhance nutrient cycling). Tree planting initiatives will need to incorporate local knowledge in dissemination to improve communication on the benefits of trees. For example, communicating how trees can rehabilitate degraded lands by reducing susceptibility of landslides and improving soil fertility, while contributing to infrastructure and protecting watersheds. Previous initiatives promoted trees because they enhanced structural connectivity and biodiversity.

Once knowledge gaps are identified, utilizing and acknowledging a common vocabulary is necessary to create effective dialogues and changed behavior (Eigenbrode et al., 2007). Specifically, Talamanca farmers use the words "cansada o esteril" tired or sterile to describe unproductive soil. They also use the term "vitamin", not nutrient, to describe nutrients needed by crops. It is important to use the local agricultural vocabulary to better communicate soil data and research results to the farmers.

As smallholder farmers continue to abort diverse agricultural systems to adopt seemingly lucrative (often monoculture) cash crops, effective dialogue between farmers, researchers and extension scientists are needed to develop innovative agricultural solutions that increase production and improve economic livelihoods. Understanding how farmers view the land and soil is an initial step to encourage effective communication and trust between involved parties to accomplish these goals. Subsistence farmers have developed knowledge of soil and its site suitability because it directly impacts their survival. In Talamanca, farmers communicated their knowledge, asked questions, and shared their ideas and concerns. Through these interactions, future project themes and workshops were identified and include: nutrient (vitamin) cycling; effects of fire on soil; and rehabilitation of degraded lands. Talamanca farmers were concerned about the productivity of the land within indigenous territories and about how their children and grandchildren will survive 
financially amidst the current socio-economic conditions. Successful extension and research projects must acknowledge farmers reliance on productive soil, incorporate the local agricultural vocabulary and beliefs, and address the current concerns of the farmers (e.g., soil degradation and low crop productivity) in order to develop integrated programs that improve both human livelihoods and soil conditions.

\section{Acknowledgements}

The authors would like to thank the Cabécar indigenous communities of Sibuju, San Vicente and San Miguel, and the indigenous associations of ADITICA, ADITIBRI, and ACOMUITA. The authors would especially like to thank Celia Lopéz and Margarita Alvarado for their logistical support and all members of the Talamanca Team. Thank you to Craig Watt for offering a Social Scientist perspective and thank you to Jodi Johnson-Maynard for your thoughtful review of this paper. This work was supported by NSF grant 0114304 and the University of Idaho College of Graduate Studies.

\section{References}

[1] Andrade, H., Detlefsen, G., 2003. Principales actores de Talamanca. Agroforestería en las Américas 10, 6-11.

[2] Bailgar, V.C., Fageria, N.K., 2005. Soil aluminum effects on growth and nutrition of cacao. Soil Science and Plant Nutrition 51, 709-713.

[3] Barrera-Bassols, N., Zinck, J.A., Van Ranst, E., 2006. Local soil classification and comparison of indigenous and technical soil maps in a Mesoamerican community using spatial analysis. Geoderma 135, 140-162.

[4] Barrios, E., Delve, R.J., Bekunda, M., Mowo, J., Agunda, J., Ramisch, J., Trejo, M.T., Thomas, R.J., 2006. Indicators of soil quality: A South-South development of a methodological guide for linking local and technical knowledge. Geoderma 135, 248-259.

[5] Barrios, E., Trejo, M.T., 2003. Implications of local soil knowledge for integrated soil management in Latin America. Geoderma 111, 217-231.

[6] Bertsch, P.M., Bloom, P.R., 1996. Aluminum. In: Sparks, D.L. (Ed.), Methods of Soil Analysis. Part 3 Chemical Methods. Soil Science Society of America and American Society of Agronomy, Madison, WI, pp. 517-543.

[7] Borge, C., Castillo, R., 1997. Cultura y conservación en la Talamanca Indígena. EUNED, San Jose.

[8] Creswell, J.W., 2003. Research Design: qualitative, quantitative, and mixed method approaches. Sage Publications, Thousand Oaks.

[9] Dahlquist, R.M., Whelan, M.P., Winowiecki, L., Polidoro, B., Candela, S., Harvey, C.A., Wulfhorst, J.D., McDaniel, P.A., Bosque-Perez, N.A., 2007. Incorporating livelihoods in biodiversity conservation: a case study of cacao agroforestry systems in Talamanca, Costa Rica. Biodiversity and
Conservation 16, 2311-2333.

[10] Dialla, B.E., 1993. The Mossi indigenous soil classification in Burkina Faso. Indigenous Knowledge and Development Monitor 1, 17-20.

[11] Dove, M.R., 1985. Swidden Agriculture in Indonesia: Subsistence strategies of the Kalimantan Kantu. Mounton Publishers, Berlin.

[12] Eigenbrode, S.D., O'Rourke, M., Wulfhorst, J.D., Altoff, D.M., Goldberg, C.S., Merril, K., Morse, W., Nielsen-Pincus, M., Stephens, J., Winowiecki, L., Bosque-Perez, N.A., 2007. Employing a Philosophical Dialogue in Collaborative Science. BioScience 57, 55-64.

[13] Ericksen, P., Ardon, M., 2003. Similarities and differences between farmer and scientist views on soil quality issues in central Honduras. Geoderma 111, 233-248.

[14] Gee, G.W., Bauder, J.W., 1986. Particle size analysis. In: Klute, A. (Ed.), Methods of Soil Analysis. Part I. . Soil Science Society of America and American Society of Agronomy, Madison, pp. 383-441.

[15] Gobin, A., Campling, P., Deckers, J., Feyen, J., 1998. Integrated toposequence analysis at the confluence zone of the River Ebonyi; headwater catchment, southeastern Nigeria. Catena 32, 173-192.

[16] Gobin, A., Campling, P., Deckers, J., Feyen, J., 2000. Integrated toposequence analysis to combine local and scientific knowledge systems. Geoderma 97, 103-123.

[17] Gomez, V.F., 2001. Analisis de seleccion de mejoras en produccion sostenible y conservacion de la biodiversidad en fincas indigenas de cacao en Talamanca, Costa Rica. CATIE, Turrialba, Costa Rica, p. 171.

[18] Gray, L.C., Morant, P., 2003. Reconciling indigenous knowledge with scientific assessment of soil fertility changes in southwestern Burkina Faso. Geoderma 111, 425-437.

[19] Grossman, J.M., 2003. Exploring farmer knowledge of soil processes in organic coffee systems of Chiapas, Mexico. Geoderma 111, 267-287.

[20] Habarurema, E., Steiner, K.G., 1997. Soil suitability classification by farmers in southern Rwanda. Geoderma 79, 75-87.

[21] IUSS Working Group WRB, 2006. World reference base for soil resources 2006: World Soil Resources Reports No. 103. FAO, Rome.

[22] Kapp, G.B., 1989. Perfil ambiental de la zona Baja de Talamanca, Costa Rica. CATIE, Turrialba, Costa Rica, p. 97.

[23] Krogh, L., Paarup-Laursen, B., 1997. Indigenous soil knowledge among the Fulani of northern Burkina Faso: linking soil science and anthropology in analysis of natural resource management. GeoJournal 43, 189-197.

[24] Municipalidad of Talamanca, 2003. Plan local de desarrollo 2003-2013. Municipality of Talamanca, Bribri, Costa Rica, p. 77.

[25] Nelson, D.W., Sommers, L.E., 1996. Total carbon, organic carbon, and organic matter. In: Sparks, D.L. (Ed.), Methods of Soil Analysis. Part 3 Chemical Methods. Soil Science Society of America and American Society of Agronomy, Madison, WI, pp. 961-1010. 
[26] Osunade, M.A.A., 1988. Soil suitability classification of small farmers. Professional Geographer 40, 194-201.

[27] Oudwater, N., Martin, A., 2003. Methods and issues in exploring local knowledge of soils. Geoderma 111, 387-401.

[28] Polidoro, B., 2007. Ecological risk assessment of current-use pesticides in the Sixaola watershed, Costa Rica. Plant, Soil and Entomological Science. University of Idaho, Moscow, USA, p. 212.

[29] Polidoro, B., Winowiecki, L., Johnson-Maynard, J.L., McDaniel, P.A., Morra, M., 2008. Suelos del valle y del piedemonte en Talamanca: un paisaje dinámico para el almacenamiento de carbono. Agroforestería en lasAméricas $46,40-44$.

[30] Ryder, R., 2003. Local soil knowledge and site suitability evaluation in the Dominican Republic. Geoderma 111, 289-305.

[31] Schusky, E.L., 1989. Culture and agriculture: An introduction to traditional and modern farming systems. Bergin and Garvey Publishers, New York.

[32] Sillitoe, P., 1998. Knowing the land: soil and land resource evaluation and indigenous knowledge. Soil Use and Management 14, 188-193.

[33] Soil Survey Staff, 2006. Keys to soil taxonomy. USDA-NRCS, Washington D.C.

[34] Somarriba, E., 1993. Allocation of farm area to crops in an unstable Costa Rican agricultural community. University of Michigan, Ann Arbor, USA, p. 165.

[35] Somarriba, E., Harvey, C., 2003. ¿Cómo integrar producción sostenible y conservación de biodiversidad en cacaotales orgánicos indígenas? Agroforestería en las Américas 10, 12-17.

[36] Somarriba, E., Trivelato, M., Villalobos, M., Súarez, A., Benavides, P., Moran, K., Orozco, L., López, A., 2003. Diagnóstico agroforestal de pequeñas fincas cacaoteras orgánicas de indígenas Bribri y Cabécar de Talamanca, Costa Rica. Agroforestería en lasAméricas 10, 24-30.
[37] Steiner, K.G., 1998. Using farmers' knowledge of soils in making research results more relevant to field practice: Experience from Rwanda. Agriculture Ecosystems and Environment 69, 191-200.

[38] Sumner, M.E., Miller, W.P., 1996. Cation exchange capacity and exchange coefficients. In: Sparks, D.L. (Ed.), Methods of Soil Analysis. Part 3 Chemical Methods. Soil Science Society of America and American Society of Agronomy, Madison, pp. 1201-1229.

[39] Talawar, S., Rhoades, R., 1998. Scientific and local classification and management of soils. Agriculture and Human Values 15, 3-14.

[40] Thomas, G.W., 1982. Exchangeable cations. In: Page, A.L. (Ed.), Methods of soil analysis. Part 2. 2nd ed. Agronomy Monograph 9. ASA and SSSA, Madison, pp. 159-165.

[41] Villalobos, M., Borge, C., 1998. Talamanca en la encrucijada. EUNED, San Jose.

[42] Whelan, M.P., 2005. Reading the Talamanca Landscape: land use and livelihoods in the Bribri and Cabécar indigenous territories. CATIE, Turrialba, p. 123.

[43] Williams, B., Ortiz-Solorio, C.A., 1981. Middle American soil folk soil taxonomy. Annals of the Association of American Geographers 71, 335-358.

[44] Winklerprins, A.M.G.A., 1999. Local soil knowledge: A tool for sustainable land management. Society and Natural Resources 12, 151-161.

[45] Winklerprins, A.M.G.A., McGrath, D.G., 2000. Smallholder agriculture along the lower Amazon floodplain, Brazil. PLEC News and Views 16, 34-42.

[46] Winklerprins, A.M.G.A., 2001. Why context matters: Local soil knowledge and management among an indigenous peasantry on the Lower Amazon Floodplain, Brazil. Etnoecologica 5, 6-20.

[47] Winklerprins, A.M.G.A., Barrera-Bassols, N., 2004. Latin American ethnopedology: A vision of its past, present, and future. Agriculture and Human Values 21, 139-1554. 